УДК 373.09.06:004.77

Коваленко Валентина Володимирівна

молодший науковий співробітник

Інститут інформаційних технологій і засобів навчання НАПН України, м. Київ, Україна

vako88@ukr.net

\title{
ПРОБЛЕМА РОЗВИТКУ КОМПЕТЕНТНОСТІ ПЕДАГОГІЧНИХ ПРАЦІВНИКІВ 3 ВИКОРИСТАННЯ ШЕВ-ОРІЕНТОВАНИХ І МУЛЬТИМЕДІЙНИХ ТЕХНОЛОГІЙ У ПЕДАГОГІЧНІЙ ТЕОРІЇ І ПРАКТИЦІ
}

\begin{abstract}
Анотація. У публікації досліджено проблему підготовки педагогічних працівників 3 використання web-орієнтованих i мультимедійних технологій у початковій школі, проаналізовано дисертаційні дослідження у цьому напрямі. Доведено важливість розвитку компетентності педагогічних працівників 3 використання web-opiєнтованих i мультимедійних технологій у роботі з учнями початкової школи. Визначено критерії (ціннісно-мотиваційний; організаційно-діяльнісний; оціночно-рефлексивний) компетентності педагогічних працівників 3 використання web-орієнтованих i мультимедійних технологій для формування соціальної компетентності учнів початкової школи.
\end{abstract}

Ключові слова: компетентність педагогічних працівників; web-орієнтовані технології; мультимедійні технології; ІКТ; учні початкової школи; соціальна компетентність.

\section{1. ВСТУП}

Нині відбуваються суттєві зміни в освітній політиці України, перед освітою постають нові завдання, одним 3 яких $є$ впровадження інформаційно-комунікаційних технологій у навчання і виховання молоді, модернізація освітньої галузі на основі іiі інформатизації.

Вітчизняні вчені [51] зазначають, що для українського освітнього простору в реаліях сучасного інформаційного суспільства особливої значущості й актуальності набули питання забезпечення високого рівня інформатизації освіти, що передбачає оволодіння педагогами уміннями впроваджувати в навчально-виховну практику електронні навчальні ресурси, застосовувати мережу Інтернет для освітніх цілей, керувати проектною діяльністю учнів із застосуванням інформаційно-комунікаційних технологій (IКТ).

Використання IКТ в навчально-виховному процесі надає не тільки широкий доступ до інформаційних джерел, а й можливість побудови власного віртуального простору перебування в інформаційному середовищі, створюючи підгрунтя для реалізації творчого потенціалу особистості [30, с. 34].

Важливим $є$ виховання i розвиток школярів відповідно до їхніх потреб i навчальних можливостей, отже, головним завданням учителів, соціальних педагогів i психологів загальноосвітніх навчальних закладів (ЗН3) постає: гармонійний розвиток школярів, виявлення неповторності й унікальності, розкриття творчих здібностей i створення умов для інтелектуального, духовного і фізичного розвитку дітей [24]. Вважаємо, що першочерговим завданням $€$ соціалізація дітей i розвиток їхньої соціальної компетентності, що сприятиме їх адаптації до реалій сучасного інформаційного суспільства.

На нашу думку, використання IКT (web-орієнтованих i мультимедійних технологій) у навчально-виховному процесі забезпечить швидке й ефективне засвоєння матеріалу завдяки багатоканальному поданню відомостей [22] i допоможе 
педагогічним працівникам, які працюють 3 дітьми у початковій школі, застосовувати їх як допоміжні засоби для формування соціальної компетентності учнів.

Враховуючи вище викладене, вважаємо, що дослідження потребує аналізу сучасного стану підвищення кваліфікації педагогічних працівників ЗНЗ щодо використання IKT, a саме web-оріснтованих i мультимедійних технологій для формування соціальної компетентності учнів початкової школи.

Аналіз останніх досліджень і публікацій. Проведено аналіз публікацій у таких аспектах:

1) підготовка і підвищення кваліфікації педагогічних працівників (Лещенко М. П. [30-32], Чичук В. М. [54] і в дослідженнях [2; 3; 6; 8; 15; 18-21; 25-26; 28-29; 33-34; $39 ; 40 ; 42 ; 45 ; 46 ; 48-50 ; 52 ; 55])$;

2) упровадження ІКТ у початкову школу (Андрієвська В. М. й Олефіренко Н. В. [1], Співаковський О. В., Петухова Л. С., Коткова В. В. [47]);

3) формування соціальної компетентності учнів початкової школи (Бібік Н. М. [4], Галакова О. В. [10], Данилейко С. I. [13], Коваленко В. В. [22-24; 37], Ніколаєску І. А. [36], Пастир Ю. І. [38], Позднякова О. Л. [41], Проценко О. В. [43], Серякова С. Б. [44], Цветков В. В. [53] і в дослідженнях [9; 27; 39]).

У результаті аналізу 3'ясовано, що недостатньо дослідженою залишається проблема розвитку компетентності педагогічних працівників 3 використання webорієнтованих і мультимедійних технологій для формування соціальної компетентності учнів початкової школи.

Мета статті. Дослідити проблему розвитку компетентності педагогічних працівників 3 використання web-орієнтованих i мультимедійних технологій $\mathrm{y}$ педагогічній теорії і практиці. У своєму дослідженні ми акцентуємо увагу на аналізі дисертаційних робіт щодо різних аспектів підготовки вчителів початкових класів, використання IКТ у початковій школі, формування соціальної компетентності учнів початкової школи.

\section{Завдання дослідження}

1. Дослідити проблему підготовки педагогічних працівників з використання webорієнтованих і мультимедійних технологій у початковій школі, проаналізувати дисертаційні дослідження у цьому напрямі.

2. Обгрунтувати актуальність розвитку компетентності педагогічних працівників 3 використання web-орієнтованих і мультимедійних технологій у роботі 3 учнями початкової школи.

3. Визначити критерії оцінювання компетентності педагогічних працівників 3 використання web-орієнтованих і мультимедійних технологій для формування соціальної компетентності учнів початкової школи.

\section{2. МЕТОДИ ДОСЛІДЖЕННЯ}

Для розв'язання поставлених у роботі завдань були використані такі методи: 1) теоретичні: аналіз і синтез, вивчення наукових публікацій i авторефератів дисертацій, систематизації й узагальнення дисертаційних досліджень щодо різних аспектів підготовки вчителів початкових класів; 2) емпіричні: спостереження, опитування педагогічних працівників початкової школи з метою визначення критеріїв оцінювання компетентності педагогічних працівників 3 використання webорієнтованих і мультимедійних технологій для формування соціальної компетентності учнів початкової школи. 


\section{3. РЕЗУЛЬТАТИ ДОСЛІДЖЕННЯ}

\section{1. Аналіз дисертаційних робіт і публікацій щодо різних аспектів підготовки вчителів початкових класів}

Проаналізовано наукові публікації щодо проблеми підготовки педагогічних працівників до використання web-орієнтованих i мультимедійних технологій у початковій школі. У [51] зазначено, що поширене використання комп'ютерів i різноманітних мультимедійних засобів у школі нині, $є$ характерним для більшості індустріальних країн світу. Сучасний навчальний процес неможливий без використання ресурсів глобальної мережі Інтернет, користування електронними бібліотеками, внутрішніх мереж і автоматизованих систем управління освітнім процесом. Швидкий Інтернет, телефонний і телекомунікаційний зв'язок пронизує щоденне життя школяра, всіх організаторів і учасників процесу навчання у школі. Інформаційні потоки, технології Веб 2.0 і Веб 3.0, хмарні технології постійно розвиваються і впливають на процес навчання.

Погоджуємося із зазначеним у [32] про те, що у результаті динамічного розвитку IКТ, важливим $є$ підвищення ІК-компетентностей громадян суспільства знань. Сучасні ІКТ створюють умови для застосування нової методології навчання й комунікації. Мультимедія, Інтернет дозволяють трансформувати знання, моделювати віртуальну пізнавальну реальність, а також створюють умови для перевірки правильності розв'язань, їх реєстрування, систематизації й поширення. Електронні медія й мультимедія дозволяють розширити простір значень, впливають на стратегії їх конструювання і розуміння, пізнання реальності й місця в ній людини як частини цієї реальності. Людина, завдяки розвиненим технологіям, може не тільки швидко орієнтуватися в культурі, виокремлювати й усвідомлювати значення, а й ставати співтворцем культури, цінностей [32, с. 123].

Нині педагогічні працівники, як представники «інформаційної спільноти» стоять перед альтернативою виконання нових особистих ролей або альтернативою вибору варіантів поведінки в мережі й контролю за власними діями в ній, що пов'язано 3 проблемою розвитку компетентності щодо використання IКТ. Важливими $є$ вміння учителя: участь у створенні спільноти у процесі мережної комунікації, зокрема побудова структур мережних взаємозв'язків і контактів; уміння реагувати на питання, проводити діалог, а також виробляти індивідуальний підхід, позбавляючись стереотипів і формалізованої поведінки; дотримання сфери приватності, себто у процесі інтеркомунікації контролювати емоції, почуття і висловлення, щоб не перетнути межі приватного простору особистості; акцентування на створенні образної презентації, що призводить до виникнення відчутних особистих і соціальних реакцій $[32$, c. 126$]$.

У Законі України «Про вищу освіту» [16] термін «компетентність» визначено як динамічну комбінацію знань, умінь і практичних навичок, способів мислення, професійних, світоглядних і громадянських якостей, морально-етичних цінностей, яка визначає здатність особи успішно здійснювати професійну і подальшу навчальну діяльність і є результатом навчання на певному рівні вищої освіти.

Співаковський О.В., Петухова Л. С. і Коткова В. В. [47] наголошують, що сучасний учитель повинен знати тенденції інформатизації освіти, психологопедагогічні умови використання IКТ у роботі з дітьми; уміти користуватися новими інформаційними освітніми технологіями, застосовувати педагогічні можливості IКТ у своїй професійній діяльності; сприяти формуванню основ ІК-компетентності та інформаційної етики учнів, сформувати в дітей відповідне уявлення про роль 
комп'ютерних технологій у їх житті. Поділяємо думку Коротиної Ю. В. [25], що вчитель початкових класів повинен уміти вдало структурувати елементи навчального матеріалу, інтегрувати різнопредметні знання, максимально застосовувати образотворчу ілюстрацію, відеотехніку та комп'ютерну графіку, анімацію, використовувати методи проблемного навчання, діалогічні форми навчання та ін. Також у [32, с. 125] вчені розглядають компетентність щодо використання медія, що включає: уміння розуміти й характеризувати роль медія - друкованих, радіо, телебачення, кінематографу, Інтернету як джерел знань i формування вмінь застосовувати їx; знання методів і засобів знаходження інформації в медія, використовуючи різні інструкції і матеріали; уміння класифікувати й оцінювати інформацію, зокрема в ситуаціях ії великого обсягу; здатність розпізнавати вид i характер повідомлення 3 огляду на адресата й цінність застосування, наприклад, інформації з книжки, преси, радіо, телебачення, фільму, Інтернету; здатність формулювати власне судження з приводу окресленої тематики на основі використання медія-повідомлень як джерела інформації й різних поглядів; здатність у різних завданнях медія-управління реєструвати, перетворювати і створювати доступ до медія комунікатів; здатність до користування 3 різноманітних інформаційних джерел різноманітних видавництв, зокрема 3 пропозицій електронних медія-видавництв [32, c. 125].

У [47] визначено, що інформатичні компетентності вчителів початкової школи $\epsilon$ комплексною характеристикою системи знань, умінь і навичок набуття і трансформації інформації в професійно-педагогічній діяльності, особистісні якості педагога, що в сукупності дають змогу майбутнім фахівцям ефективно здійснювати професійну діяльність з усвідомленим передбаченням іï наслідків і постійним професійним саморозвитком. Водночас, у [32, с. 132-133] зазначено, що до найважливіших компетентностей громадянина інформаційного суспільства потрібно віднести вміння здобувати потрібну мультимедійну інформацію, iï декодувати, інтерпретувати, критично проаналізувати, відібрати, перетворити, генерувати нову інформацію, опублікувати і презентувати іiі для зацікавлених реципієнтів. Усі названі вміння належать до комунікаційних компетентностей, що відображено у стандартах підготовки вчителя до використання ІКТ. Застосування ІКТ у професійній підготовці передбачає формування професійних компетентностей, серед яких є ті, що вимагають творчих або інноваційних дій. Серед стандартів професійних компетентностей учителів повинні бути компетентності праксеологічні, комунікаційні, моральні, технологічні тощо. Учитель повинен уміти стимулювати розвиток здібностей учнів, їхніх зацікавлень і ставлення до творчості, сприяти креативній поведінці, самостійності їхнього мислення, і при цьому всьому повинен сам уміти критично мислити [32, с. 132133].

Ми погоджуємось 3 думкою багатьох науковців і практиків, що в сучасному інформаційному суспільстві першочерговою вимогою до педагогічних працівників $\epsilon$ постійне підвищення їх кваліфікації, зокрема, вчителів початкових класів, адже вони створюють умови для всебічного розвитку дитини, формування іiі особистості й соціалізації. В умовах інформаційного простору на формування соціальної компетентності молодших школярів впливає низка факторів: родина, друзі, мобільні пристрої, телебачення, Інтернет мережа та іiі наповнення (web-сайти, соціальні мережі, web-канали тощо).

Аналіз наукової літератури, переважно авторефератів дисертаційних робіт щодо проблеми підготовки педагогічних працівників, а саме вчителів початкових класів, дозволив зробити зведену таблицю 1 , у якій представлено тематику захищених досліджень з 1999 по 2014 рік в Україні. 
Дисертаційні роботи щодо проблеми підготовки вчителів початкових класів

\begin{tabular}{|c|c|c|c|}
\hline № & Автор & Назва дисертації & $\begin{array}{l}\text { Науковий ступінь, } \\
\text { назва спеціальності, } \\
\text { рік захисту }\end{array}$ \\
\hline 1 & Хомич Л. О. & $\begin{array}{l}\text { Система психолого-педагогічної підготовки вчителя } \\
\text { початкових класів }\end{array}$ & $\begin{array}{l}\text { д. пед. н., 13.00.04, } \\
1999 \text { р. }\end{array}$ \\
\hline 2 & Коломієць А. М. & $\begin{array}{l}\text { Tеоретичні та методичні основи формування } \\
\text { iнформаційної культури майбутнього вчителя } \\
\text { початкових класів }\end{array}$ & $\begin{array}{l}\text { д. пед. н., 13.00.04, } \\
2008 \text { р. }\end{array}$ \\
\hline 3 & Пєтухової Л. Є. & 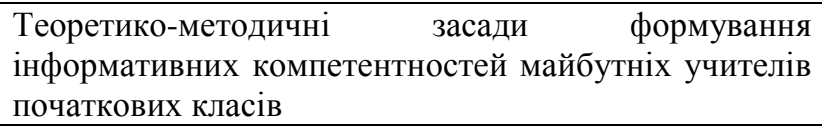 & $\begin{array}{l}\text { д. пед. н., 13.00.04, } \\
2009 \text { р. }\end{array}$ \\
\hline 4 & Комар О. А. & \begin{tabular}{llllr} 
Tеоретичні & та методичні & засади & \multicolumn{2}{c}{ підготовки } \\
майбутніх & учителів початкової & школи & до \\
застосування інтерактивної технології & & \\
\end{tabular} & $\begin{array}{l}\text { д. пед. н., 13.00.04, } \\
2011 \text { р. }\end{array}$ \\
\hline 5 & Литвиненко С. А. & $\begin{array}{l}\text { Tеоретико-методичні засади підготовки } \\
\text { учйелбутніх } \\
\text { педагогічної діяльності } \\
\end{array}$ & $\begin{array}{l}\text { д. пед. н., 13.00.04, } \\
2005 \text { р. }\end{array}$ \\
\hline 6 & Долинський Б. Т. & $\begin{array}{l}\text { Теоретико-методичні засади підготовки майбутніх } \\
\text { учителів до формування здоров'язбережувальних } \\
\text { навичок і вмінь у молодших школярів у навчально- } \\
\text { виховній діяльності }\end{array}$ & $\begin{array}{l}\text { д. пед. н., 13.00.04, } \\
2011 \text { р. }\end{array}$ \\
\hline 7 & Філіпп’єва О. А. & $\begin{array}{l}\text { Підготовка майбутніх учителів початкових класів до } \\
\text { валеологічного виховання учнів }\end{array}$ & $\begin{array}{l}\text { к. пед. н., 13.00.04, } \\
2008 \text { р. }\end{array}$ \\
\hline 8 & Сінопальнікова Н. М. & $\begin{array}{lll}\text { Педагогічні умови підготовки майбутніх учителів до } \\
\text { застосування інтегрованих форм } & \text { організації } \\
\text { навчального процесу в початковій школі } & \end{array}$ & $\begin{array}{l}\text { к. пед. н., 13.00.04, } \\
2010 \text { р. }\end{array}$ \\
\hline 9 & Макаренко Л. Л. & $\begin{array}{l}\text { Комп'ютерна грамотність як складова професійної } \\
\text { підготовки майбутніх учителів початкової школи }\end{array}$ & $\begin{array}{l}\text { к. пед. н., 13.00.04, } \\
2007 \text { р. }\end{array}$ \\
\hline 10 & Імбер В. I. & $\begin{array}{l}\text { Педагогічні умови застосування мультимедійних } \\
\text { засобів навчання у підготовці майбутнього вчителя } \\
\text { початкових класів }\end{array}$ & $\begin{array}{l}\text { к. пед. н., 13.00.04, } \\
2008 \text { р. }\end{array}$ \\
\hline 11 & Смирнова I. М. & $\begin{array}{l}\text { Формування інформаційної культури } \\
\text { учителів початббутніх } \\
\end{array}$ & $\begin{array}{l}\text { к. пед. н., 13.00.04, } \\
2004 \text { р. }\end{array}$ \\
\hline 12 & Наливайко Г. В. & $\begin{array}{l}\text { Розвиток самоосвітньої компетентності вчителів } \\
\text { початкових класів у системі підвищення кваліфікації }\end{array}$ & $\begin{array}{l}\text { к. пед. н., 13.00.04, } \\
2012 \text { р. }\end{array}$ \\
\hline 13 & Скоробогатова М. Р. & $\begin{array}{l}\text { Розвиток системи підготовки вчителів початкових } \\
\text { класів в Україні (друга половина XX сторіччя) }\end{array}$ & $\begin{array}{l}\text { к. пед. н., 13.00.01, } \\
2010 \text { р. }\end{array}$ \\
\hline 14 & Барановська В. М. & $\begin{array}{l}\text { Методична система формування інформатичних } \\
\text { компетентностей майбутніх учителів початкових } \\
\text { класів }\end{array}$ & $\begin{array}{l}\text { к. пед. н., 13.00.02, } \\
2014 \text { р. }\end{array}$ \\
\hline 15 & Шиман О. I. & 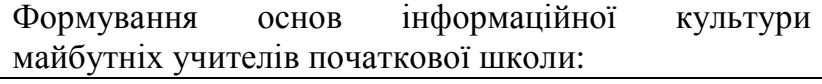 & $\begin{array}{l}\text { к. пед. н., 13.00.02, } \\
2005 \text { р. }\end{array}$ \\
\hline 16 & Кірейчев А. В. & $\begin{array}{l}\text { Формування психологічної готовності майбутніх } \\
\text { вчителів початкових класів до профілактики і } \\
\text { корекції проявів дитячої агресивності }\end{array}$ & $\begin{array}{l}\text { к. } \quad \text { психол. } \\
19.00 .07,2008 \text { р. }\end{array}$ \\
\hline 17 & Бєкірова Л. Е. & $\begin{array}{l}\text { Формування готовності майбутніх учителів } \\
\text { початкових класів до застосування інтерактивних } \\
\text { технологій навчання }\end{array}$ & $\begin{array}{l}\text { к. пед. н., 13.00.04, } \\
2010 \text { р. }\end{array}$ \\
\hline 18 & Снігур О. М. & $\begin{array}{l}\text { Формування вмінь використовувати засоби } \\
\text { інформаційних технологій у майбутній професійній } \\
\text { діяльності вчителя початкової школи }\end{array}$ & $\begin{array}{l}\text { к. пед. н., 13.00.09, } \\
2007 \text { р. }\end{array}$ \\
\hline 19 & Вовк В. П. & $\begin{array}{l}\text { Психологічна підготовка вчителя початкових класів } \\
\text { до роботи із соціально занедбаними учнями }\end{array}$ & $\begin{array}{l}\text { к. психол. } \\
\text { 19.00.07, } 2007 \text { p. }\end{array}$ \\
\hline 20 & Суховірський О. В. & $\begin{array}{l}\text { Підготовка майбутнього вчителя початкової школи } \\
\text { до використання інформаційних технологій }\end{array}$ & $\begin{array}{l}\text { к. пед. н., 13.00.04, } \\
2005 \text { р. }\end{array}$ \\
\hline 21 & Петриченко Л. О. & Підготовка майбутнього вчителя початкової школи & к. пед. н., 13.00.04, \\
\hline
\end{tabular}




\begin{tabular}{|c|c|c|c|}
\hline & & до інноваційної діяльності в позааудиторній роботі & 2007 p. \\
\hline 22 & Поліщук Л. П. & $\begin{array}{l}\text { Професійна підготовка вчителів початкової школи } \\
\text { Англії в умовах євроінтеграції }\end{array}$ & $\begin{array}{l}\text { к. пед. н., 13.00.01, } \\
2011 \text { р. }\end{array}$ \\
\hline 23 & Короткова Ю. М. & $\begin{array}{l}\text { Професійна підготовка вчителя початкових класів у } \\
\text { сучасній Греції }\end{array}$ & $\begin{array}{l}\text { к. пед. н., 13.00.01, } \\
2008 \text { р. }\end{array}$ \\
\hline 24 & Клименюк Ю. М. & $\begin{array}{l}\text { Підготовка майбутнього вчителя до розвитку } \\
\text { інтелектуальної обдарованості учнів початкової } \\
\text { школи }\end{array}$ & $\begin{array}{l}\text { к. пед. н., 13.00.04, } \\
2009 \text { р. }\end{array}$ \\
\hline 25 & Пастир Ю. І. & $\begin{array}{l}\text { Підготовка майбутнього вчителя до соціалізації } \\
\text { молодших школярів }\end{array}$ & $\begin{array}{l}\text { к. пед. н., 13.00.04, } \\
2010 \text { р. }\end{array}$ \\
\hline 26 & Зімакова Л. В. & $\begin{array}{l}\text { Підготовка майбутніх учителів початкових класів до } \\
\text { соціалізації учнів засобами театрального мистецтва }\end{array}$ & $\begin{array}{l}\text { к. пед. н., 13.00.04, } \\
2004 \text { р. }\end{array}$ \\
\hline 27 & Котух Н. В. & $\begin{array}{l}\text { Підготовка майбутніх учителів початкових класів до } \\
\text { формування комунікативних умінь учнів в умовах } \\
\text { відкритої соціально-педагогічної системи }\end{array}$ & $\begin{array}{l}\text { к. пед. н., 13.00.04, } \\
2005 \text { р. }\end{array}$ \\
\hline 28 & Казанжи I. B. & $\begin{array}{l}\text { Підготовка майбутніх учителів початкових класів до } \\
\text { позаурочної виховної роботи }\end{array}$ & $\begin{array}{l}\text { к. пед. н., 13.00.04, } \\
2002\end{array}$ \\
\hline 29 & Баранова О. А. & $\begin{array}{l}\text { Підготовка майбутніх учителів початкових класів до } \\
\text { попереджувально-корекційної роботи з учнями }\end{array}$ & $\begin{array}{l}\text { к. пед. н., 13.00.04, } \\
2001 \text { р. }\end{array}$ \\
\hline 30 & Філатова Л. С. & $\begin{array}{l}\text { Підготовка майбутніх учителів початкових класів до } \\
\text { організації спілкування учнів у процесі розвиваючих } \\
\text { ігор }\end{array}$ & $\begin{array}{l}\text { к. пед. н., 13.00.04, } \\
2002 \text { р. }\end{array}$ \\
\hline
\end{tabular}

Аналіз авторефератів дисертаційних робіт щодо різних аспектів підготовки вчителів початкових класів показав, що дослідження переважно спрямовані на підготовку майбутніх учителів початкових класів, а не вчителів-практиків. У результаті аналізу виявлено, що малодослідженими $є$ проблеми підготовки вчителів початкових класів до використання web-орієнтованих і мультимедійних технологій у професійній діяльності.

Співаковський О. В, Пєтухова Л. Є. і Коткова В. В. зазначають, що використання IКТ, а саме web-орієнтованих і мультимедійних технологій у початковій школі, має значний вплив на виховання дітей: естетичне виховання за рахунок використання можливостей комп'ютерної графіки, технології мультимедія; виховання комп'ютерної комунікативної етики. Інформаційно-комунікаційна підтримка навчального процесу розвиває наочно-образний, наочно-дієвий, інтуїтивний, творчий види мислення школяра; комунікативні здібності; формує вміння приймати оптимальне рішення або пропонувати варіанти рішень у складній ситуації; розвиває навички самоосвіти i самоконтролю; закладає основи інформаційної культури і початки розвитку вмінь здійснювати опрацювання відомостей. ІКТ дозволяють істотно змінити способи керування навчальною діяльністю, залучити учнів до активної роботи класу [47].

У сучасних умовах становлення інформаційного суспільства актуальним $\epsilon$ постійне підвищення кваліфікації вчителів, зокрема, учителів початкових класів, оскільки саме вони закладають і створюють умови для розвитку дитини і формування іiі особистості. Тому автором проаналізовано вітчизняні дисертаційні дослідження щодо різних аспектів використання IКТ у початковій школі, що відображено у таблиці 2.

Проведений аналіз дисертаційних робіт щодо різних аспектів використання IКТ у початковій школі, дозволив зробити висновок про наявність незначної кількості робіт щодо використання web-орієнтованих i мультимедійних технологій педагогічними працівниками у початковій школі, на нашу думку, ця проблема $є$ актуальною і потребує подальшого дослідження.

Розглянемо детальніше розвиток компетентності педагогічних працівників 3 використання web-орієнтованих і мультимедійних технологій у роботі з учнями початкової школи. 
Дисертаційні роботи щодо проблеми використання IКТ у початковій школі

\begin{tabular}{|c|c|c|c|}
\hline № & Автор & Назва дисертації & $\begin{array}{c}\text { Науковий ступінь, } \\
\text { назва спеціальності, } \\
\text { рік захисту }\end{array}$ \\
\hline 1 & Коломієць Н. А. & $\begin{array}{l}\text { Дидактичні засади застосування } \text { інтерактивних } \\
\text { методів навчання молодших школярів }\end{array}$ & $\begin{array}{l}\text { к. пед. н., 13.00.09, } \\
2009 \text { р. }\end{array}$ \\
\hline 2 & Чорноус О. В. & \begin{tabular}{llll} 
Формування & \multicolumn{2}{c}{ навчально-організаційних } & умінь і \\
навичок & молодших & школярів & засобами \\
відеоінформації & & \\
\end{tabular} & $\begin{array}{l}\text { к. пед. Н., 13.00.09, } \\
2010 \text { р. }\end{array}$ \\
\hline 3 & Дмор С. Ма. М. & $\begin{array}{l}\text { Методика навчання молодших школярів футболу у } \\
\text { процесі позаурочних занять } 3 \text { використанням } \\
\text { iнформаційних технологій }\end{array}$ & $\begin{array}{l}\text { к. пед. н., 13.00.02, } \\
2014 \text { р. }\end{array}$ \\
\hline 4 & Заря Л. О. & $\begin{array}{l}\text { Методика формування у молодших школярів } \\
\text { інтересу до музики з використанням мультимедійних } \\
\text { технологій }\end{array}$ & $\begin{array}{l}\text { к. пед. н., 13.00.02, } \\
2013 \text { р. }\end{array}$ \\
\hline
\end{tabular}

Нині система освіти потребує нових підходів до організації навчально-виховного процесу, зокрема у початковій школі, адже вчителі часто змушені працювати 3 проблемою зниження рівня пізнавальної активності учнів, небажанням працювати самостійно і просто вчитися. Серед багатьох причин втрати молодшими школярами інтересу до навчання можна назвати одноманітність уроків. Відсутність можливості повсякденного пошуку нової, цікавої інформації призводить до шаблонного викладання, а це руйнує і знищує інтерес учнів до навчання. Творчий підхід учителя до побудови та проведення уроку, насиченість різноманітними прийомами, методами та формами викладання зможуть забезпечити його ефективність. Одним зі способів розвитку пізнавальної активності є використання інформаційних технологій, що дають змогу привернути увагу учнів до навчання [47].

Погоджуємося 3 твердженням Коротиної Ю. В. [25, с. 15], що серед компонентів формування в індивіда потреби у неперервній освіті на сучасному етапі, найістотнішим $\epsilon$ саме розвиток його творчих можливостей. Працювати творчо - необхідна вимога до професійної діяльності сучасного фахівця. Сучасний учитель початкових класів повинен уміти структурувати елементи навчального матеріалу, інтегрувати різнопредметні знання, максимально застосовувати образотворчу ілюстрацію, відеотехніку та комп'ютерну графіку, анімацію, використовувати методи проблемного навчання, діалогічні форми навчання та ін.

Нині актуальною $є$ проблема творчості вчителя в контексті ІКТ, що розглядається на основі різних підходів. Розуміння творчості, що виявляється у витворах, грунтується на аналізі результатів креативної діяльності. Категорія гуманістичної творчості вживається для позначення творчих, індивідуальних витворів учителя. Вона охоплює матеріали, що розміщуються на інтернет-сторінках шкіл, освітніх порталах (документація педагогічних експериментів, нові методичні підходи, авторські програми вчителів, мультимедійні матеріали, програми, що допомагають формуванню компетентностей, дидактичні засоби - мультимедійні презентації, флеш-програми створені вчителями, а також візуальні матеріали (комп'ютерна графіка, літературні тексти), аудіоматеріали (художнє декламування, читання літературних текстів, музична творчість), аудіовізуальні матеріали (фільми, відеоролики). Тобто, мультимедійна комп'ютерна програма або інтернет-сторінка бази даних, мультимедійні презентації, програми, якщо характеризуються новими, рідко вживаними елементами $є$ творчим витвором учителя [32, с. 127-130].

Для вчителя важливим є удосконалення вмінь: опрацювання інформації в різних формах; комунікація і співпраця 3 іншими вчителями із застосуванням IКT; 
розв’язування проблем; проведення досліджень у контексті викладання предмету; відбір матеріалів і накопичення інформації для створення мультимедійних презентацій на основі нагромадженої й опрацьованої інформації в електронній версії; презентування навчальних чи виховних матеріалів для учнів із застосуванням електронних освітніх засобів, таких як: дидактичні ігри, веб-сайти, інтернет-сторінки, списки і дискусійні групи. У світлі цього аналізу закономірним є питання про зміст компетентності вчителя, який на практиці міг би реалізувати творчий підхід [32, с. 134136].

Багато вчених переконані, що використання в навчально-виховному процесі сучасних ІКТ надає не тільки широкий доступ до інформаційних джерел, інтерактивний характер взаємодії з інформацією, а й можливість побудови власного простору перебування в інформаційному середовищі, у якому розмаїття способів представлення інформації (різні форми створення віртуальної реальності) створюють підгрунтя для реалізації творчого потенціалу особистості. Відповідно до цих реалій педагогічна наука має переорієнтуватися на розвиток самодостатньої, духовно розвиненої та щасливої особистості в умовах існуючих і реалій, які постійно виникають [30].

Застосування сучасних ІКТ у навчальному процесі спричиняє зростання вимоги до професійної підготовки вчителя, його інформаційно-комунікаційної компетентності, до обсягу його знань, культури мови, поведінки. Учитель повинен мати певною мірою універсальні, фундаментальні знання, щоб мати можливість ефективно в педагогічному плані використовувати засоби сучасних інформаційно-комунікаційних технологій, створювати для учнів умови для повного розкриття їхнього творчого потенціалу, здібностей і здатностей, задоволення запитів і навчально-пізнавальних потреб [35].

Аналіз наукових робіт 3 розвитку компетентності педагогічних працівників (підвищення кваліфікації практиків) щодо використання web-оріснтованих i мультимедійних технологій у роботі з учнями початкової школи, показав, що ця проблема є актуальною і малодослідженою.

\section{2. Аналіз дисертаційних робіт щодо формування соціальної компетентності учнів початкової школи}

Беззаперечним є факт, що одним із важливих напрямів роботи ЗНЗ, є створення умов для формування соціальної компетентності учнів, а отже, провідним завданням учителів, соціальних педагогів і психологів є: гармонійний розвиток школярів, їх неповторності й унікальності, розкриття їх творчості і створення умов для інтелектуального, духовного i фізичного розвитку. Відповідно до Державного стандарту початкової загальної освіти України «соціальну компетентність» визначено як здатність особистості продуктивно співпрацювати 3 різними партнерами у групі та команді, виконувати різні ролі та функції у колективі. У дослідженні [4] «соціальна компетентність» розуміється як здатність жити в соціумі (ураховувати інтереси і потреби різних соціальних груп; дотримуватися соціальних норм i правил; співпрацювати 3 різними партнерами), а також адекватно виокремлювати, ідентифікувати, фіксувати та аналізувати коло питань на перетині всієї системи соціальних відносин суспільства людини [4]. Під «соціальною компетентністю молодшого школяра» вчені у роботах [43;44] визначають: 1) знання, уміння, навички та здібності, які потрібні учню для подальшої освіти в постійно змінних соціальних умовах; 2) інтеграційну особистісну характеристику, що відображає визнання цінності себе й іншого, співпраці з дітьми і дорослими; знання правил поведінки і взаємодії, способів виходу з конфліктних ситуацій, що виявляється в шанобливому ставленні до 
людей різного віку і різних культур, у відповідальності за свої вчинки і результати діяльності на основі розвитку рефлексії [44].

Саме робота 3 формування соціальної компетентності учнів початкових класів сприятиме виконанню суспільних завдань поставлених перед сучасними вчителями, соціальними педагогами i психологами, які працюють у ЗНЗ. Автором були проаналізовані вітчизняні і зарубіжні дисертаційні дослідження, спрямовані на формування соціальної компетентності учнів початкової школи, що представлені в таблиці 3.

Таблиия 3

Дисертаційні роботи щодо проблеми формування соціальної компетентності учнів початкової школи

\begin{tabular}{|c|c|c|c|}
\hline № & Автор & Назва дисертації & $\begin{array}{c}\text { Науковий ступінь, } \\
\text { назва спеціальності, } \\
\text { рік захисту }\end{array}$ \\
\hline 1 & Коротина Ю. В. & $\begin{array}{l}\text { Формирование социальной компетентности младших } \\
\text { школьников средствами учебных предметов }\end{array}$ & $\begin{array}{l}\text { к. пед. н., 13.00.02, } \\
2011 \text { р. }\end{array}$ \\
\hline 2 & Галакова О. В. & $\begin{array}{l}\text { Развитие социальной } \text { компетентности } \\
\text { школьников во внеурочной деятельности }\end{array}$ & к. пед. н., 2013 р. \\
\hline 3 & Цветков В. В. & $\begin{array}{l}\text { Формирование социальной компетентности сельских } \\
\text { школьников }\end{array}$ & к. пед. н., 2002 р. \\
\hline 4 & Позднякова О. Л. & $\begin{array}{l}\text { Формування соціальної компетентності учнів } 3 \\
\text { обмеженими можливостями здоров’я } \\
\text { проектної діяльності }\end{array}$ & $\begin{array}{l}\text { к. пед. н., 13.00.03, } \\
2010 \text { р. }\end{array}$ \\
\hline
\end{tabular}

Проведений аналіз дисертаційних робіт щодо різних аспектів формування соціальної компетентності учнів початкової школи дозволив зробити висновок про те, що малодослідженим $\epsilon$ питання щодо використання web-орієнтованих i мультимедійних технологій педагогічними працівниками для формування соціальної компетентності учнів початкової школи, а тому ця проблема є актуальною і потребує подальшого дослідження.

\section{3. Аналіз поняття web-оріснтованих $\mathrm{i}$ мультимедійних технологій $\mathbf{y}$ науковій літературі}

Аналіз наукової літератури [5; 22-23; 35] доводить позитивний вплив наочності на швидкість сприйняття даних і визначає переваги використання web-opiєнтованих i мультимедійних технологій у навчально-виховному процесі, що грунтуються на зоровому і слуховому сприйнятті, які забезпечують швидке й ефективне засвоєння матеріалу завдяки багатоканальному поданню відомостей. Автором на практиці доведено, що учням початкової школи подобаються уроки 3 використанням webорієнтованих і мультимедійних технологій. Під час проведення таких уроків у класі створюються умови для активного спілкування учнів з учителем та однолітками, вони прагнуть висловити свої думки, із задоволенням виконують різні завдання, виявляють зацікавленість до матеріалу, що вивчається. Ці технології можуть використовуватись, і як супровід навчального процесу і з метою виховного впливу [22].

Наголосимо, що використання web-орієнтованих і мультимедійних технологій у початковій школі, потребує врахування певних факторів, зокрема: психофізіологічного розвитку учнів початкових класів; особливостей навчально-пізнавальної діяльності учнів; дидактичного потенціалу web-орієнтованих i мультимедійних технологій, орієнтованих на початкову школу; організаційно-педагогічних умов використання webорієнтованих і мультимедійних технологій у навчанні; вимог до впровадження web- 
орієнтованих і мультимедійних технологій у навчально-виховний процес початкової школи (ергономічні вимоги; вимоги до змісту навчального матеріалу та ін.) [22].

Для нашого дослідження важливим $є$ визначення поняття «web-opiєнтованих i мультимедійних технологій». Під «web-технологією» розуміють: 1) сукупність методів i програмно-технічних засобів, інтегрованих з метою ефективного опрацювання webресурсів, які містяться у web-просторі. Поняття web-технологій пов'язано з методами i засобами створення web-сторінок із підтримкою мультимедія, що поєднують у собі різні види інформації (текст, графіку, звук, анімацію та відео), таке визначення webтехнологій охоплює базові сервіси Інтернету; 2) комплекс технічних, комунікаційних, програмних методів розв'язання завдань організації спільної діяльності користувачів із застосування мережі Інтернет [5; 12; 22; 35; 47]. Також, Буйницькою О. П. та Гончаренком С. У. [5; 12] поняття «мультимедійні технології» визначено як технології, що дозволяють за допомогою комп'ютера інтегрувати, опрацьовувати і водночас відтворювати різноманітні типи сигналів, різні середовища, засоби і способи обміну інформацією [5], «мультимедійні засоби навчання» - це комплекс апаратних i програмних засобів, що дозволяють користувачеві працювати 3 комп'ютером, використовуючи різноманітні середовища: графіку, гіпертексти, звук, анімацію, відео $[12$, c. 298$]$.

У [22] автором рекомендовано застосовувати web-орієнтовані і мультимедійні технологій для формування соціальної компетентності учнів початкової школи, а саме: мультиплікаційні фільми, відеоролики, фільми, соціальні мережі, комп'ютерні ігри, чати, дитячі портали, мультимедійні презентації, мультимедія-тренажери, електронні підручники, енциклопедії тощо [22].

Вважаємо, що у систему підвищення кваліфікації вчителів початкових класів, соціальних педагогів і шкільних психологів, варто включити питання щодо розвитку їх компетентності 3 використання web-орієнтованих i мультимедійних технологій, зокрема для формування соціальної компетентності учнів початкових класів.

3.4. Критерії оцінювання компетентності педагогічних працівників 3 використання web-оріснтованих і мультимедійних технологій для формування соціальної компетентності учнів початкової школи

На основі проаналізованої наукової літератури щодо розвитку ІК-компетентності педагогічних працівників i власного практичного досвіду, автором розроблено i обгрунтовано три критерії компетентності педагогічних працівників щодо використання web-орієнтованих i мультимедійних технологій для формування соціальної компетентності учнів початкової школи. Охарактеризуємо їх детальніше:

1) ціннісно-мотиваційний (знання основних термінів і понять; формування соціальної компетентності молодших школярів; усвідомлення важливості компетентності 3 використання web-орієнтованих i мультимедійних технологій у професійні діяльності; мотивація до використання web-орієнтованих і мультимедійних технологій);

2) організаційно-діяльнісний (уміння застосовувати web-орієнтовані і мультимедійні технологій для формування соціальної компетентності молодших школярів);

3) оціночно-рефлексивний (добір web-орієнтованих і мультимедійних ресурсів для формування соціальної компетентності молодших школярів; критичне оцінювання web-орієнтованих і мультимедійних ресурсів; удосконалення особистих навичок і вмінь щодо використання web-орієнтованих і мультимедійних технологій у формуванні соціальної компетентності молодших школярів). 
Оцінювання сформованості компетентності педагогічних працівників щодо використання web-орієнтованих технологій для формування соціальної компетентності учнів початкової школи пропонуємо здійснювати за такими рівнями: базовий, функціональний та творчий.

\section{4. ВИСНОВКИ ТА ПЕРСПЕКТИВИ ПОДАЛЬШИХ ДОСЛІДЖЕНЬ}

Аналіз наукової літератури, а саме дисертаційних досліджень, показав, що у розглянутих роботах малодосліджені питання: 1) підвищення кваліфікації педагогічних працівників (учителів початкових класів, соціальних педагогів, шкільних психологів) до використання web-орієнтованих i мультимедійних технологій у професійній діяльності; 2) різні аспекти впровадження web-орієнтованих i мультимедійних технологій у початковій школі; 3) використання web-орієнтованих і мультимедійних технологій педагогічними працівниками для формування соціальної компетентності учнів початкової школи. Вважаємо, що ці питання $є$ актуальними і потребують подальшого дослідження.

Вважаємо, що використання web-орієнтованих і мультимедійних технологій для формування соціальної компетентності учнів початкової школи, буде успішним за умови педагогічно виваженого добору web-opiєнтованих і мультимедійних технологій i застосування їх не тільки у школі, а й для позакласної і позашкільної роботи з учнями.

На підставі проаналізованих наукових досліджень і власного практичного досвіду, нами розроблено й обгрунтовано критерії компетентності педагогічних працівників щодо використання web-орієнтованих i мультимедійних технологій для формування соціальної компетентності учнів початкової школи: ціннісномотиваційний; організаційно-діяльнісний; оціночно-рефлексивний. Для оцінювання сформованості компетентності педагогічних працівників щодо використання webорієнтованих технологій для формування соціальної компетентності учнів початкової школи рекомендовано застосовувати такі рівні: базовий, функціональний та творчий.

Напрямки подальших розвідок передбачають обгрунтування моделі й розробку методики використання web-орієнтованих технологій для формування соціальної компетентності учнів початкових класів.

\section{СПИСОК ВИКОРИСТАНИХ ДЖЕРЕЛ}

1. Андрієвська В. М. Мультимедійні технології у початковій ланці освіти [Електронний ресурс] / В. М. Андрієвська, Н. В. Олефіренко // Інформаційні технології і засоби навчання. - 2010. - № 2 (16). - Режим доступу до журналу : http://www.ime.edu-ua.net/em.html.

2. Баранова О. А. Підготовка майбутніх учителів початкових класів до попереджувально-корекційної роботи з учнями : автореф. дис... канд. пед. наук : 13.00 .04 / О. А. Баранова ; Центр. ін-т післядиплом. пед. освіти АПН України. - К., 2001. - 22 с.

3. Бєкірова Л. Е. Формування готовності майбутніх учителів початкових класів до застосування інтерактивних технологій навчання : автореф. дис. ... канд. пед. наук : 13.00.04 / Л.Е. Бєкірова ; Унт менедж. освіти НАПН України. - К., 2010. - 20 с.

4. Бібік Н. М. Компетентність і компетенції у реультатах початкової освіти / Н. М. Бібік // Початкова школа. - 2010. - №9. - С. 1-4.

5. Буйницька О. П. Інформаційні технології та технічні засоби навчання / О. П. Буйницька // Навч. посіб. - К. : Центр учбової літератури, 2012. - 240 с.

6. Вовк В. П. Психологічна підготовка вчителя початкових класів до роботи із соціально занедбаними учнями : автореф. дис... канд. психол. наук : 19.00.07 / В. П. Вовк ; Ін-т психології ім. Г.С. Костюка АПН України. - К., 2007. - 20 с. 
7. Гавриш Н. В. Орієнтація на розвиток суб'єктності студента у процесі підготовки професійно компетентних фахівців з дошкільної освіти / Н. В. Гавриш // Збірник наукових праць Бердянського державного педагогічного університету (Педагогічні науки). Бердянськ : БДПУ, 2007. — С. 44-49.

8. Гайдур М. І. Підготовка майбутніх вчителів до організації навчально-пізнавальної діяльності молодших школярів в умовах інформаційного середовища: автореф. дис. ... канд. пед. наук : 13.00.04 / М. І. Гайдур ; Крим. гуманіт. ун-т. - Ялта, 2010. - 20 с.

9. Галакова О. В. Развитие социальной компетентности младших школьников во внеурочной деятельности : дис. ... канд. пед. наук. / О. В. Галакова. - М., 2013. - 203 с.

10. Галакова О. В. Роль педагога-психолога в развитии социальной компетентности младших школьников / О. В. Галакова // Информация и образование : границы коммуникаций. - 2013. - № 5 (13). - C. 271- 272.

11. Головань М. С. Компетенція і компетентність : досвід теорії, теорія досвіду // Вища освіта України. - 2008. - № 3. - С. 23-30.

12. Гончаренко С. У. Український педагогічний енциклопедичний словник / С. У. Гончаренко. [Видання друге, доповнене й виправлене]. - Рівне : Волинські обереги, 2011. - 552 с.

13. Данилейко С..І.Шляхи формування соціальної компетентності учнів початкової школи [Електронний ресурс] / С. І. Данилейко / Матеріали наукової конференції «Соціум. Наука. Культура» - Режим доступу : http://intkonf.org/-danileyko-si-shlyahi-formuvannya-sotsialnoyikompetentnosti-uchniv-pochatkovoyi-shkoli/.

14. Державний стандарт початкової загальної освіти, затверджений постановою Кабінету Міністрів України від 20 квітня 2011 р. № 462 [Електронній ресурс]. - Режим доступу : http://zakon4.rada.gov.ua/laws/show/462-2011-\%D0\%BF.

15. Долинський Б. Т. Теоретико-методичні засади підготовки майбутніх учителів до формування здоров'язбережувальних навичок і вмінь у молодших школярів у навчально-виховній діяльності : автореф. дис. ... д-ра пед. наук : 13.00 .04 / Б. Т. Долинський ; ДЗ «Південноукр. нац. пед. ун-т ім. К.Д. Ушинського». - О., 2011. - 45 с.

16. Закон України «Про вищу освіту» [Електронний ресурс]. - Режим доступу : http://zakon5.rada.gov.ua/laws/show/1556-18.

17. Закон України «Про основні засади розвитку інформаційного суспільства в Україні на 2007-2015 роки» [Електронний ресурс]. - Режим доступу до джерела : http://zakon4.rada.gov.ua/laws/show/537-16.

18. Зімакова Л. В. Підготовка майбутніх учителів початкових класів до соціалізації учнів засобами театрального мистецтва : автореф. ... канд. пед. наук: 13.00 .04 / Л. В. Зімакова ; Ін-т педагогіки і психології проф. освіти АПН України. - К., 2004. - 20 с.

19. Казанжи І. В. Підготовка майбутніх учителів початкових класів до позаурочної виховної роботи : автореф. ... канд. пед. наук: 13.00.04 / I. В. Казанжи ; Південноукр. держ. пед. ун-т ім. К. Д. Ушинського. - О., 2002. - 20 с.

20. Кірейчев А. В. Формування психологічної готовності майбутніх вчителів початкових класів до профілактики і корекції проявів дитячої агресивності : автореф. дис... канд. психол. Наук : 19.00.07 / А. В. Кірейчев ; Південноукр. держ. пед. ун-т ім. К.Д.Ушинського. - О., 2008. - 20 с.

21. Клименюк Ю. М. Підготовка майбутнього вчителя до розвитку інтелектуальної обдарованості учнів початкової школи: автореф. дис... канд. пед. наук: 13.00.04 / Ю. М. Клименюк ; Житомир. держ. ун-т ім. І. Франка. - Житомир, 2009. - 20 с.

22. Коваленко В. В. Особливості використання web-орієнтованих і мультимедійних технологій у формуванні соціальної компетентності молодших школярів / В. В. Коваленко // Інформатика та інформаційні технології в навчальних закладах. № 5-6 (58) Київ, 2015. - С. 3-7.

23. Коваленко В. В. Проблеми підготовки вчителя i соціального педагога до застосування мультимедійних засобів для формування основ здоров'я молодших школярів [Електронний ресурс] / В. В. Коваленко // Інформаційні технології і засоби навчання. - 2013. - №5 (37). - С. 8998. - Режим доступу до журналу : http://journal.iitta.gov.ua/index.php/itlt/-issue/view/62.

24. Коваленко В. В. Формування соціальної компетентності молодших школярів в умовах сучасного інформаційного простору / В. В. Коваленко // Щомісячний науково-методичний журнал «Освіта та розвиток обдарованої особистості» Київ, 2015. - №6 (37) - С. 37-40.

25. Коломієць А. М. Теоретичні та методичні основи формування інформаційної культури майбутнього вчителя початкових класів: автореф. дис. ...д.пед.н. : 13.00.04 «Теорія і методика професійної освіти» / А. М. Коломієць. - К. : 2008. - 45 с.

26. Комар О. А. Теоретичні та методичні засади підготовки майбутніх учителів початкової школи до застосування інтерактивної технології : автореф. дис. ... д-ра пед. наук : 13.00 .04 / О. А. Комар ; Черкас. нац. ун-т ім. Б. Хмельницького. - Черкаси, 2011. - 40 с. 
27. Коротина Ю. В. Формирование социальной компетентности младших школьников средствами учебных предметов: дисс. ... канд.. пед. наук : 13.00.02.. - Тамбов, 2011. - 210 с.

28. Короткова Ю. М. Професійна підготовка вчителя початкових класів у сучасній Греції : автореф. дис... канд. пед. наук : 13.00.01 / Ю. М. Короткова ; Харківський національний пед. ун-т ім. Г.С.Сковороди. - Х., 2008. - 20 с.

29. Котух Н. В. Підготовка майбутніх учителів початкових класів до формування комунікативних умінь учнів в умовах відкритої соціально-педагогічної системи : автореф. дис... канд. пед. наук : 13.00.04 / Н.В. Котух ; Кіровоград. держ. пед. ун-т ім. В. Винниченка. - Кіровоград, 2005. - 20 с.

30. Лещенко М. П. Підходи до стандартизації сформованості інформаційно-комунікаційної компетентності учнів : польський досвід [Електронний ресурс] / М. П. Лещенко, Л. І. Тимчук // Інформаційні технології і засоби навчання. - 2014 - Т. 42. - № 4. - С. 33-46. - Режим доступу : http://journal.iitta.gov.ua/index.-php/itlt/article/view/1118/828\#.VDPTllctrSg.

31. Лещенко М. П. Розвиток інформаційно-комунікаційних і медія компетентностей учителів у міжнародному педагогічному просторі [Електронний ресурс] / М. П. Лещенко, Л. І. Тимчук // Інформаційні технології і засоби навчання. - 2013. - Том 38, № 6. - Режим доступу до журналу : http://journal.iitta.gov.ua/index.php/itlt/article/view/931/696\#.VUfbMvntmko.

32. Лещенко М. П. Розвиток медія-компетентностей учителів у сучасному інформаційному суспільстві : польський досвід / М. П. Лещенко, Л. І. Тимчук // Формування інформаційнокомунікаційних компетентностей у контексті євроінтеграційних процесів створення інформаційного освітнього простору : посібник / за заг. ред. Бикова В. Ю., Овчарук О. В. ; НАПН України, Ін-т інформ. технол. і засобів навч. - К. : Атіка, 2014. - С. 122-138.

33. Литвиненко С. А. Теоретико-методичні засади підготовки майбутніх учителів початкових класів до соціально-педагогічної діяльності : автореф. дис... д-ра пед. наук : 13.00 .04 / С. А. Литвиненко ; Нац. пед. ун-т ім. М. П. Драгоманова. - К., 2005. - 40 с.

34. Макаренко Л. Л. Комп'ютерна грамотність як складова професійної підготовки майбутніх учителів початкової школи : автореф. дис... канд. пед. наук : 13.00 .04 / Л. Л. Макаренко ; Нац. пед. ун-т ім. М. П.Драгоманова. - К., 2007. - 22 с.

35. Мультимедійні системи як засоби інтерактивного навчання : посібник / За редакцією : Жука Ю. О. - К. : Педагогічна думка, 2012. - 112 с.

36. Ніколаєску I. А. Формування соціальної компетентності учнів загальноосвітніх навчальних закладів відповідно до вимог нових державних освітніх стандартів : наук.-метод. посіб. / І.А. Ніколаєску. - Черкаси : ОІПОПП, 2014. - 76 с.

37. Овчарук О. В. Формування та оцінювання ІК-компетентності у шкільній практиці України та зарубіжжя [Електронний ресурс] / О. В. Овчарук, В. В. Коваленко// Зб. матеріал. III Всеукр. наук.практ. конф. молодих учених «Наукова молодь-2015». - К. : ІІТЗН НАПН України, 2015. - С. $44-$ 47 - Режим доступу : http://lib.iitta.gov.ua/704728/.

38. Пастир Ю. І. Педагогічний супровід процесу соціалізації молодших школярів : методичні рекомендації / Ю. І. Пастир. - Ізмаїл, 2009. - 186 с.

39. Пастир Ю. І. Підготовка майбутнього вчителя до соціалізації молодших школярів : автореф. ... канд. пед. наук : 13.00.04 / Ю. І. Пастир ; Черкас. нац. ун-т ім. Б.Хмельницького. - Черкаси, 2010. $20 \mathrm{c}$.

40. Петриченко Л. О. Підготовка майбутнього вчителя початкової школи до інноваційної діяльності в позааудиторній роботі : автореф. дис... канд. пед. наук : 13.00 .04 / Л. О. Петриченко ; Кіровоград. держ. пед. ун-т ім. В. Винниченка. - Кіровоград, 2007. - 20 с.

41. Позднякова О. Л. Формування соціальної компетентності учнів з обмеженими можливостями здоров'я засобами проектної діяльності : автореф. дис ... канд. пед. наук : 13.00.03 / О. Л. Позднякова. - Київ, 2010 . - 22 с.

42. Поліщук Л. П. Професійна підготовка вчителів початкової школи Англії в умовах євроінтеграції: автореф. дис. ... канд. пед. наук : 13.00.01 / Л. П. Поліщук; Житомир. держ. ун-т ім. І. Франка. Житомир, 2011. - 20 с.

43. Проценко О. В. Соціальна компетентність молодших школярів як предмет наукових досліджень / О. В. Проценко // Педагогіка формування творчої особистості у вищій і загальноосвітній школах : зб. наук. пр. / [редкол. : Т.І. Сущенко (голов. ред.) та ін.]. - Запоріжжя : КПУ, 2014. - Вип. 35 (88). - C. 451-457.

44. Серякова С. Б. Диагностика социальной компетентности младшего школьника / С. Б. Серякова, О. В. Галакова // Перспективы науки. - 2012. - № 32. - С. 330-333.

45. Сінопальнікова Н. М. Педагогічні умови підготовки майбутніх учителів до застосування інтегрованих форм організації навчального процесу в початковій школі : автореф. дис. ... канд. пед. наук : 13.00 .04 / Н. М. Сінопальнікова ; Харк. нац. пед. ун-т ім. Г. С. Сковороди. - Х., 2010. $20 \mathrm{c}$. 
46. Снігур О. М. Формування вмінь використовувати засоби інформаційних технологій у майбутній професійній діяльності вчителя початкової школи : автореф. дис... канд. пед. наук : 13.00 .09 / O.М. Снігур ; Ін-т педагогіки АПН України. - К., 2007. - 22 с.

47. Співаковський О.В.Інформаційно-комунікаційні технології в початковій школі : Навч.-метод. посібник для студентів напряму підготовки «Початкова освіта» / О. В Співаковський, Л. Є. Петухова, В. В. Коткова. - Херсон, 2011. - 267 с.

48. Суховірський О. В. Підготовка майбутнього вчителя початкової школи до використання інформаційних технологій : автореф. дис... канд. пед. наук: 13.00 .04 / О. В. Суховірський ; Ін-т педагогіки АПН України. К., 2005. - 20 с.

49. Філатова Л. С. Підготовка майбутніх учителів початкових класів до організації спілкування учнів у процесі розвиваючих ігор : Автореф. дис... канд. пед. наук : 13.00 .04 / Л. С. Філатова ; Харк. держ. пед. ун-т ім. Г. С. Сковороди. - Х., 2002. - 19 с.

50. Філіпп’єва О. А. Підготовка майбутніх учителів початкових класів до валеологічного виховання учнів : автореф. дис... канд. пед. наук: 13.00.04 / О. А. Філіпп'єва ; Кіровоградський держ. педагогічний ун-т ім. Володимира Винниченка. - Кіровоград, 2008. - 20 с.

51. Формування інформаційно-комунікаційних компетентностей у контексті євроінтеграційних процесів створення інформаційного освітнього простору : посібник / За заг. ред. Бикова В. Ю., Овчарук О. В. ; НАПН України, Ін-т інформ. технол. і засобів навч. - К. : Атіка, 2014. - 212 с.

52. Хомич Л. О. Система психолого-педагогічної підготовки вчителя початкових класів : автореф. дис... д-ра пед. наук : 13.00.04 / Л. О. Хомич ; Ін-т педагогіки і психології проф. освіти АПН України. - К., 1999. - 38 с.

53. Цветков В. В. Формирование социальной компетентности сельских школьников : автореф. дис. на получение учён. степеня канд. пед. наук : спец. 13.00.01 «Общая педагогика, история педагогики и образования» / В. В. Цвєтков. - Великий Новгород, 2002. - 23 с.

54. Чичук В. М. Стан проблеми підготовки вчителя до використання мультимедійних технологій у початкових класах / В. М. Чичук / Розвиток педагогічної науки в Україні і Польщі на початку XXI століття : зб. наук. праць. - Черкаси : Видавець Чабаненко Ю. А., 2011. - С. 722-27.

55. Шиман О. І. Формування основ інформаційної культури майбутніх учителів початкової школи : автореф. дис... канд. пед. наук: 13.00.02 / О. І. Шиман ; Нац. пед. ун-т ім. М. П.Драгоманова. - К., 2005. $-20 \mathrm{c}$.

\title{
ПРОБЛЕМА РАЗВИТИЯ КОМПЕТЕНТНОСТИ ПЕДАГОГИЧЕСКИХ РАБОТНИКОВ ПО ИСПОЛЬЗОВАНИЮ ШЕВ-ОРИЕНТИРОВАННЫХ И МУЛЬТИМЕДИЙНЫХ ТЕХНОЛОГИЙ В ПЕДАГОГИЧЕСКОЙ ТЕОРИИ И ПРАКТИКЕ
}

\author{
Коваленко Валентина Владимировна \\ младший научный сотрудник \\ Институт информационных технологий и средств обучения НАПН Украины, г. Киев, Украина \\ vako88@ukr.net
}

\begin{abstract}
Аннотация. В публикации осуществлен анализ проблемы подготовки педагогических работников к использованию web-ориентированных и мультимедийных технологий в начальной школе, проанализированы диссертационные исследования в этом направлении. Обоснована актуальность развития компетентности педагогов по использованию webориентированных и мультимедийных технологий в работе с учениками начальной школы. Описаны критерии (ценностно-мотивационный; организационно-деятельностный; оценочно-рефлексивный) компетентности педагогических работников по использованию web-ориентированных и мультимедийных технологий для формирования социальной компетентности учеников начальной школы.
\end{abstract}

Ключевые слова: компетентность педагогических работников; web-ориентированные технологии; мультимедийные технологии; ИКТ ученики начальной школы; социальная компетентность. 


\title{
PROBLEM OF COMPETENCE DEVELOPMENT OF PEDAGOGICAL EMPLOYEES ON THE USE OF WEB-ORIENTED AND MULTIMEDIA TECHNOLOGIES IN PEDAGOGICAL THEORY AND PRACTICE
}

\author{
Valentyna V. Kovalenko \\ junior researcher \\ Institute of Information Technologies and Learning Tools of NAES of Ukraine, Kyiv, Ukraine \\ vako88@ukr.net
}

\begin{abstract}
In the article it is investigated the problem of preparation of pedagogical employees to the use of web-oriented and multimedia technology in primary school, as well as analyzed the dissertation researches in this area. It is proved the importance of competence development of pedagogical employees with the use of web-oriented and multimedia technologies while working with primary school pupils. The competence criteria of pedagogical employees with the use of web-oriented and multimedia technologies for the formation of social competence of primary school pupils were determined.
\end{abstract}

Keywords: competence of pedagogical employees; web-oriented technologies; multimedia technology; ICT; pupils of primary school; social competence.

\section{REFERENCES (TRANSLATED AND TRANSLITERATED)}

1. Andriewska V. M. Multimedia technologies in primary link of education [online] / V. M. Andriewska, N. V. Olefirenko // Information technologies and learning tools. - 2010. - № 2 (16). - Available from: http://www.ime.edu-ua.net/em.html. (in Ukrainian).

2. Baranova O.A. Training of primary school teachers to preventive and correctional work with pupils : Author. Thesis Candidate of Pedagogical Sciences : 13.00.04 / O.A. Baranova; Center. Inst. Postgraduate pedagogical education AES Ukraine. - K., 2001. - 22 p. (in Ukrainian).

3. Byekirova L.E. The formation of future elementary school teachers to use of interactive technology training : Thesis Candidate of Pedagogical Sciences : 13.00.04 / L.E. Byekirova; Education Management University NAES of Ukraine. - K., 2010. - 20 p. (in Ukrainian).

4. Bibik N.M. The expertise and competence in the results of primary education / N.M. Bibik // Elementary School. - 2010. - № 9. - P. 1-4. (in Ukrainian).

5. Buynytska O.P. Information technology and technical means of training / O.P Buynytska // Training Manual. - K. : Center of educational literature, 2012. - 240 p. (in Ukrainian).

6. Vovk V.P. Psychological training of primary school teachers to work with disadvantaged students : Author. Thesis Candidate of Psychological Sciences : 19.00.07 / Vovk V.P. ; Institute of Psychology. G.S. Kostyuka NAES of Ukraine. - K., 2007. - 20 p. (in Ukrainian).

7. Gavrish N.V. Focusing on the the development of student of subjectivity in preparing professionally of competent specialists in of preschool education / N.V. Gavrish // Collection of scientific papers of Berdyansk State Pedagogical University (Pedagogical Sciences). - Berdyansk : BDPU, 2007. - P. 44-49. (in Ukrainian).

8. Haydur M.I. Preparation of the future teachers to the teaching and learning of primary school children in the information environment : Author. Thesis Candidate of Pedagogical Sciences : 13.00.04 / M.I. Haydur ; Crimean Humanitarian University. - Yalta, 2010. - 20 p. (in Ukrainian).

9. Galakova O.V. The development of social competence of younger schoolboys in after-hour activity : Dissertation of the candidate of pedagogical sciences. / O.V. Galakova - M., 2013. 203 p. (in Russia).

10. Galakova O.V. The role of the teacher-psychologist in development of social competence of younger schoolboys / O.V. Galakova // Information and education : of communications boundaries. - 2013. - № 5 (13). - P. 271-272. (in Russia).

11. Golovan M.S. The competence and expertise, experience theory, theory of experience // Higher education Ukraine. - 2008. - № 3. - P. 23-30. (in Ukrainian).

12. Goncharenko U.S. Ukrainian Pedagogical Encyclopedic Dictionary / U. S. Goncharenko. Second edition, supplemented and revised. - Rivne : Volyntalismans, 2011. - 552 p. (in Ukrainian).

13. Danyleyko S.I. Ways of formation of social competence elementary school students [online] / S.I. Danyleyko / Materials of scientific conference «Society. Science. Kultura» - Available from: 
http://intkonf.org/-danileyko-si-shlyahi-formuvannya-sotsialnoyi-kompetentnosti-uchnivpochatkovoyi-shkoli) (in Ukrainian).

14. State standard for elementary general education, approved by the Cabinet of Ministers of Ukraine of 20.04.2011 № 462 [online]. - Available from: http://zakon4.rada.gov.-ua/laws/show/462-2011$\%$ D0\% BF. (in Ukrainian).

15. Dolinsky B.T. Theoretical and methodological principles of training of teachers to formation health preservation skills in primary school children in educational activities : Author. Dis. Dr. ped. Sciences : 13.00.04 / B.T. Dolinsky; Of State Institution «South Ukrainian National Pedagogical University named after. K.D. Ushinskogo» - O., 2011. - 45 p. (in Ukrainian).

16. The Law of Ukraine «On Higher Education» [online]. - Available from: http://zakon5.rada.gov.ua/laws/show/1556-18. (in Ukrainian).

17. Law of Ukraine «On Basic Principles of Information Society Development in Ukraine for 20072015» [online]. - Available from: http://zakon4.rada.-gov.ua/laws/show/537-16. (in Ukrainian).

18. Zimakova L.V. Preparation future elementary school teachers to of pupils by means of socialization of theatrical art : Author. Thesis Candidate of Pedagogical Sciences : 13.00 .04 / L.V. Zimakova ; The Institute of pedagogy and psychology professor. Education APN Ukraine. K., 2004. - 20 p. (in Ukrainian).

19. Kazanzhy I.V. Preparing future primary school teachers to extracurricular of educational work : Author. Thesis Candidate of Pedagogical Sciences : 13.00 .04 / I.V. Kazanzhy; South Ukrainian National Pedagogical University named after. K.D. Ushinskogo. - O., 2002. - 20 p. (in Ukrainian).

20. Kireychev A.V. Formation of of psychological readiness of future teachers of initial classes to of prevention and correction of manifestations of of child aggression : Author. Thesis Candidate of Psychology Sciences : 19.00.07 / A.V. Kireychev; South Ukrainian National Pedagogical University named after. K.D. Ushinskogo. - O., 2008. - 20 p. (in Ukrainian).

21. Klimenyuk Y.M. Preparation of the future teacher to development intellectual giftedness elementary school students : Thesis Candidate of Pedagogical Sciences : 13.00 .04 / Y.M. Klimenyuk; Zhytomyr. state. University of them. I. Franko. - Zhytomyr, 2009. - 20 p. (in Ukrainian).

22. Kovalenko V.V. Features of use of web-oriented technologies and media in shaping social competence junior pupils / V.V. Kovalenko // Computer science and information technology in schools. № 5-6 (58) Kyiv, 2015. - P. 3-7. (in Ukrainian).

23. Kovalenko V.V. Problems of training of teacher and social worker to use multimedia tools for formation of bases of junior pupils health [online] / VV Kovalenko // Information technologies and learning tools - 2013. - №5 (37). - P. 89-98. - Available from: http://journal.iitta.gov.ua/index.php/itlt/-issue/view/62. (in Ukrainian).

24. Kovalenko V.V. Formation of of social competence of younger schoolboys in the modern information space / V.V. Kovalenko // Monthly scientific-methodical journal «Education and development of gifted personality» - Kyiv, 2015. - № 6 (37) - P. 37-40. (in Ukrainian).

25. Kolomyjets A.N. Theoretical and Methodical Basis of Formation of Future Primary School Teacher's Information Culture : Author. Thesis Dr. ped. Sciences : 13.00 .04 - Theory and Methods of Professional Education / A.N. Kolomyjets. - K., 2008. - 45 p. (in Ukrainian).

26. Komar A.A. Theoretical and methodological principles of training of primary school teachers to use interactive technology : Author. Thesis Dr. ped. Sciences : 13.00.04 / A.A. Komar; Cherkasy. National University of them. B. Khmelnitsky. - Cherkasy, 2011. - 40 p. (in Ukrainian).

27. Korotina Y.V. Formation of social competence of younger schoolboys means of subjects : the Thesis Candidate of Pedagogical Sciences : 13.00.02. - Tambov, 2011. - 210 p. (in Russia).

28. Korotkova Y.M. Professional training of initial classes of teacher in modern Greece : Author. Thesis candidate. ped. Sciences : 13.00.01 / Y.M. Korotkova; Kharkov National Pedagogical. University of them. G.S. Skovoroda. - Kharkov, 2008. - 20 p. (in Ukrainian).

29. Kotuh N.V. Preparation future primary school teachers to formation of communicative skills of pupils in an open social and pedagogical systems : Author. Thesis candidate. ped. Sciences : 13.00.04 / N.V. Kotuh ; Kirovograd. state. ped. University of them. V.Vynnychenko. Kirovograd, 2005. - 20 p. (in Ukrainian).

30. Leshchenko M.P. The approaches to formation of of standardization of information and communication competence disciples : Polish experience [online] / M.P. Leshchenko, L.I. Timchuk // Information technologies and means of teaching. - 2014 - T. 42. - № 4. - P. 33-46. Available from: http://journal.iitta.gov.ua/index.-php/itlt/article/view/1118/828\#.VDPTllctrSg. (in Ukrainian). 
31. Leshchenko M.P. The development of information and communication and media competence teachers in pedagogical international space [online] / M.P. Leshchenko, L.I. Timchuk // Information technologies and means of teaching. - 2013. - Volume 38, № 6. Available from: http://journal.iitta.gov.ua/index.php/itlt/article/view/931/696\#.VUfbMvntmko. (in Ukrainian).

32. Leshchenko M.P. The development of media competence teachers in today's information society : Polish experience / Leshchenko M.P., Timchuk L.I. // Formation of information and communication competence in the context of European integration processes in an information educational space : manual / Pod Society. Ed. V.U. Bykov, O.V. Ovcharuk ; NAES Ukraine, Inst inform. techn. and means to teach. - K. : Atika, 2014. - P. 122-138. (in Ukrainian).

33. Litvinenko S.A. Theoretical and methodological basis for of preparation future elementary school teachers to social and of pedagogical activity : Author. Thesis Dr. ped. Sciences: 13.00.04 / S.A. Litvinenko; Nat. ped. University of them. M.P. Dragomanova. - K., 2005. - 40 p. (in Ukrainian).

34. Makarenko L.L. Computer literacy as a part of professional training future primary school teachers : Author. Thesis candidate. ped. Sciences : 13.00 .04 / L.L. Makarenko; Nat. ped. University of them. M.P. Dragomanova. - K., 2007. - 22 p. (in Ukrainian).

35. Multimedia systems as interactive learning means, manual / Edited by : Y.O. Zhuk - K. : Pedagogical opinion, 2012. -112 p. (in Ukrainian).

36. Nikolayesku I.A. Formation of of social competence of of pupils general educational institutions in accordance with the requirements of new state educational standards : scientific- methodical manual / I.A. Nikolayesku. - Cherkasy : OIPOPP, 2014. - 76 p. (in Ukrainian).

37. Ovcharuk O.V. Formation of and evaluation of IC competence in school practice in Ukraine and abroad [online] / O.V. Ovcharuk, V.V. Kovalenko // Coll. material. III All-Ukrainian scientific practical conference. of young scientists «Scientific the young 2015». - K. : IITZN NAES Ukraine, 2015 - P. 44-47. - Available from: http://lib.iitta.gov.ua/704728/. (in Ukrainian).

38. Pastir Y.I. Pedagogical accompaniment of younger schoolchildren of the socialization process : Methodical Recommendations / Y.I. Pastir - Izmail, 2009. - 186 p. (in Ukrainian).

39. Pastir Y.I. Preparation of future teacher for socialization for younger schoolboys : Author. Candidate. ped. Sciences : 13.00 .04 / Y.I. Pastir; Cherkasy. nat. University of them. B. Khmelnitsky. - Cherkasy, 2010. - 20 p. (in Ukrainian).

40. Petrychenko L.A. Preparation of the future teacher of elementary school to innovation activities in extracurricular work : Author. Thesis candidate. ped. Sciences : 13.00 .04 / L.A. Petrychenko; Kirovograd. state. ped. University of them. V.Vynnychenko. - Kirovograd, 2007. - 20 p. (in Ukrainian).

41. Pozdnyakova O.L. Formation of of social competence pupils with limited abilities of health by means project activity : Author. Thesis candidate. ped. Sciences : 13.00.03 / O.L. Pozdnyakova. Kiev, 2010. - 22 p. (in Ukrainian).

42. Polischuk L.P. Professional training of primary school teachers of England in terms of European integration : Author. Thesis Candidate. ped. Sciences : 13.00.01 / L.P. Polishchuk; Zhytomyr. state. University of them. I. Franko. - Zhytomyr, 2011. - 20 p. (in Ukrainian).

43. Protsenko O.V. Social competence junior pupils as a subject of scientific research / O.V. Protsenko // Pedagogy formation of creative personality in higher and general schools : Coll. Science. pr. / [redkol. : T.I. Sushchenko (chairman. Ed.) Et al.]. - Zaporozhye : CPU, 2014. - Vol. 35 (88). - P. 451-457. (in Ukrainian).

44. Seryakova S.B. Diagnosis of social competence of the younger schoolboy / S.B. Seryakova, A.V. Halakova // Prospects of Science, 2012. - № 32. - P. 330-333. (in Ukrainian).

45. Sinopalnikova N.M. Pedagogical conditions of training of teachers to use integrated forms organization of educational process in elementary school : Author. Dis. Candidate. ped. Sciences : 13.00.04 / N.M. Sinopalnikova ; Khark. nat. ped. University of them. G.S. Skovoroda. - Kh., 2010. - 20 p. (in Ukrainian).

46. Snegur A.M. Formation of skills to use of information technology means in their future careers an elementary school teacher : Author. Thesis candidate. ped. Sciences: 13.00.09 / A.M. Snegur; Institute of Pedagogy NAES of Ukraine. - K., 2007. - 22 p. (in Ukrainian).

47. Spivakovsky A.V. ICT in primary school: Teach method. manual for students field of study «Primary education»/ A.V. Spivakovsky, L.E. Petukhova, V.V. Kotkova. - Kherson - 2011. 267 p. (in Ukrainian).

48. Suhovirskyy O.V. Preparation of the future teacher of elementary school to use of information technology : Author. Thesis candidate. ped. Sciences : 13.00 .04 / O.V. Suhovirskyy; Institute of Pedagogy NAES of Ukraine. - K., 2005. - 20 p. (in Ukrainian).

49. Filatova L.S. Preparation future elementary school teachers in the organization of communication of pupils during of educational games : Author. Thesis candidate. ped. Sciences : 13.00.04 / 
L.S. Filatov; Khark. state. ped. University of them. G.S. Skovoroda. - Kh., 2002. -19 p. (in Ukrainian).

50. Filipp'yeva O.A. Preparation future elementary school teachers to education of pupils of valeological : Author. Thesis candidate. ped. Sciences: 13.00.04 / O.A. Filipp'yeva; Kirovograd State. Pedagogical University named after. Vynnychenko. - Kirovograd, 2008. - 20 p. (in Ukrainian).

51. Formation of the Information and Communication competence in the context of European integration processes in an information educational space : manual / Pod Society. Ed. V.U. Bykov, O.V. Ovcharuk ; NAES of Ukraine, Inst inform. techn. and means to teach. - K. : Atika, 2014. 212 p. (in Ukrainian).

52. Khomich L.A. The system of psychological andpedagogical training of initial classes of teacher: Author. Thesis Dr. ped. Sciences : 13.00.04 / L.A. Khomich ; The Institute of pedagogy and psychology prof. Education APS of Ukraine. - K., 1999. -38 p. (in Ukrainian).

53. Chychuk V.M. State of the Problem of Teacher Training for Use of Multimedia Technologies in Primary Classes / V.M. Chychuk / Development of pedagogical science in the Ukraine and Poland in the early twenty-first century : Coll. Science. works. - Cherkasy : Publisher Chabanenko Y.A., 2011. - P. 722-727. (in Ukrainian).

54. Tsvetkov V.V. Devising social of competence of rural schoolboys : Author. Dis. to kand.ped degree. Sciences : specialty 13.00.01 «The total pedagogy, history of pedagogy and education» / V.V. Tsvetkov - Grand Novgorod, 2002. - 23 p. (in Russia).

55. Schiemann O.I. Formation of of information culture future primary school teachers : Author. Thesis candidate. ped. Sciences : 13.00.02 / O.I. Schiemann ; Nat. ped. University of them. M.P. Dragomanova. - K., 2005. - 20 p. (in Ukrainian).

Conflict of interest. The author has declared no conflict of interest.

\section{(c) EY-NC-SA}

This work is licensed under Creative Commons Attribution-NonCommercial-ShareAlike 4.0 International License. 